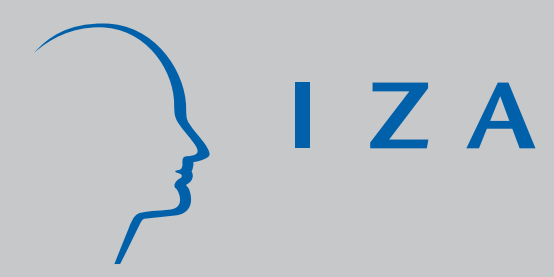

IZADP No. 3494

Immigrants and Welfare Programmes: Exploring

the Interactions between Immigrant Characteristics, Immigrant Welfare Dependence and Welfare Policy

Alan Barrett

Yvonne McCarthy

May 2008 


\title{
Immigrants and Welfare Programmes: Exploring the Interactions between Immigrant Characteristics, Immigrant Welfare Dependence and Welfare Policy
}

\author{
Alan Barrett \\ Economic and Social Research Institute \\ and IZA \\ Yvonne McCarthy \\ Central Bank and Financial Services Authority of Ireland
}

Discussion Paper No. 3494

May 2008

IZA

P.O. Box 7240

53072 Bonn

Germany

Phone: $+49-228-3894-0$

Fax: +49-228-3894-180

E-mail: iza@iza.org

\begin{abstract}
Any opinions expressed here are those of the author(s) and not those of IZA. Research published in this series may include views on policy, but the institute itself takes no institutional policy positions.

The Institute for the Study of Labor (IZA) in Bonn is a local and virtual international research center and a place of communication between science, politics and business. IZA is an independent nonprofit organization supported by Deutsche Post World Net. The center is associated with the University of Bonn and offers a stimulating research environment through its international network, workshops and conferences, data service, project support, research visits and doctoral program. IZA engages in (i) original and internationally competitive research in all fields of labor economics, (ii) development of policy concepts, and (iii) dissemination of research results and concepts to the interested public.
\end{abstract}

IZA Discussion Papers often represent preliminary work and are circulated to encourage discussion. Citation of such a paper should account for its provisional character. A revised version may be available directly from the author. 


\section{ABSTRACT \\ Immigrants and Welfare Programmes: Exploring the Interactions between Immigrant Characteristics, Immigrant Welfare Dependence and Welfare Policy ${ }^{*}$}

The primary purpose of this paper is to provide a review of the papers within the economics literature that have examined the questions of immigrant welfare use and the responsiveness of immigrants to the incentives created by welfare systems. While our focus is largely on papers looking at the European case, we also draw on studies from the United States, in particular on issues where the European literature is thin. One set of papers asks whether immigrants who are more likely to use welfare are attracted to more generous welfare states. The results from these papers are not clear-cut. Another set of papers asks if immigrants use welfare more intensively than natives and if they assimilate out of or into welfare participation. In most cases, the unadjusted data shows higher use of welfare by immigrants although for some countries, for example Germany, this difference can be explained by differences in characteristics. Yet another set of papers finds that the rate of welfare use by existing migrants can influence the welfare use of newly arrived co-nationals. We illustrate some of these issues by looking at immigrant welfare use in Ireland and the UK. Immigrants in the UK appear to use welfare more intensively than natives but the opposite appears to be the case in Ireland.

JEL Classification: $\quad$ I38, J61

Keywords: immigrants, welfare participation, Ireland, U.K.

Corresponding author:

Alan Barrett

Economic and Social Research Institute

Whitaker Square

Sir John Rogerson's Quay

Dublin 2

Ireland

E-mail: Alan.Barrett@esri.ie

\footnotetext{
${ }^{*}$ This is a first draft of a paper being prepared in response to an invitation from the Oxford Review of Economic Policy. We would like to acknowledge the help provided by Mark Taylor in accessing the BHPS. Any views expressed are those of the authors and not necessarily those of either the ESRI or the CBFSAI.
} 


\section{Immigrants and Welfare Programmes: Exploring the Interactions between Immigrant Characteristics, Immigrant Welfare Dependence and Welfare Policy}

\section{Section 1: Introduction}

The economics literature contains a large number of papers on various aspects of immigrants' experiences in their host countries. However, the vast bulk of these studies have tended to look at the labour market experiences of immigrants, partly through studies of earnings but also through studies of occupational attainment and the incidence of unemployment. One aspect of immigrants' experiences that has attracted less attention in the economics literature is the extent to which immigrants receive welfare payments in their host countries. A related and even less-explored issue is the extent to which migration decisions are influenced by welfare systems in host countries.

In this paper, we aim to provide a comprehensive review of the papers within the discipline of economics that have examined the questions of immigrant welfare use and the responsiveness of immigrants to the incentives created by welfare systems. While our focus is largely on papers looking at the European case, it is useful to draw on studies from the United States, in particular on issues where the European literature is thin.

Our review is structured as follows. We begin by looking at the question of whether immigrant inflows are influenced by the nature of the welfare system. Our interest will be on the composition of the inflow rather than on the size because the key question here is whether immigrants who are more likely to need welfare are more heavily concentrated in inflows to generous welfare states. We then go on to look at whether immigrants are more likely to be in receipt of benefits relative to natives. Within this section, we draw on papers that ask if any differences between immigrants and natives in welfare receipt are the result of migrant status per se or are the result of differences in characteristics between immigrants and natives, where those characteristics are associated with a greater propensity towards welfare use. Another theme that is addressed is whether certain contextual factors influence the likelihood 
of immigrants receiving welfare, such as the extent to which co-nationals are also in receipt of welfare.

In addition to the review just outlined, we also include an analysis of immigrant welfare receipt in Ireland and the UK. In this analysis, we ask whether immigrants in Ireland and the UK are more or less likely to be in receipt of welfare payments relative to the native population. While this analysis is meant to act partly as a way of illustrating some of the issues that arise in the literature review, the results that emerge are of interest in themselves.

As a final note in this Introduction, it is worth mentioning that the relatively small amount of papers on immigration and welfare is possibly at odds with the amount of public debate (and concern) about the extent to which immigrants use welfare. Many of the papers that are reviewed below begin with the observation that concerns over a perceived heavy utilisation of welfare by immigrants are a central feature of public debate on immigration. To the extent that this paper draws useful lessons from the literature, it is hoped that we can contribute to filling a potential gap in the economics literature.

Section 2: Does the generosity of a state's welfare system induce low-skilled immigration?

Borjas (1999) looks at the issue of whether differences in welfare regimes lead to differences in the nature of the immigrant inflow across the states of the U.S.. He notes that there are a number of dimensions to the hypothesis that welfare can act as a “magnet”. First, it could be that immigrants come to the U.S. in response to the incentives created by the existence of welfare benefits. Second, immigrants who fail to secure employment or who become unemployed may be less likely to out-migrate. Third, differences in the relative generosity of welfare systems across states can lead to a pattern of settlement of immigrants that leads to higher welfare burdens in the more generous states. Interestingly, Borjas also notes that “(d)espite their importance, there has been little systematic study of these magnetic effects” (p 608). 
Borjas develops a model of immigrant location in which states vary in terms of the generosity of their welfare systems and also in terms of the returns to skills. While natives are assumed to face fixed costs of migration across states, these costs are not relevant to immigrants for whom the choice between states is costless, given that the decision to move has been made. The model leads to a number of predictions, including the greater clustering of low-skill (and hence more welfare-prone) migrants relative to natives in states with more generous welfare systems. The model also predicts that the change in the welfare participation rate brought about by a change in the benefit level should be higher in the immigrant population relative to the native population ("benefits elasticity”, as labelled by Borjas).

With regard to the clustering hypothesis, Borjas notes that a relatively high proportion of immigrant households in receipt of welfare reside in California, a state with a high level of welfare generosity. In 1990, California was home to 9.6 percent of the native U.S. population who did not receive benefits and home to 11.5 percent who did receive benefits. Also in 1990, 27.6 percent of immigrants who were not on welfare lived in California compared to 37.6 percent of immigrants who were in receipt of benefits. This observation prompts Borjas to assert that "there may indeed exist a purposive clustering of less-skilled immigrants in California” (p 618). A more formal analysis in which he controls for demographic and socioeconomic factors, and also for possible networks effects, yields a result of excess clustering of immigrant welfare recipients.

The evidence presented by Borjas with regard to his estimates of differences in benefit elasticity across immigrants and natives is less conclusive. While a range of specifications point to a higher benefit elasticity for immigrants, the differences are generally not statistically significant. Borjas himself makes the following important point in his concluding paragraph: "Because of the potential policy significance of these findings, it is important to emphasize that much of the empirical evidence presented in this article is relatively weak (in the sense that the statistical significance of the results is often marginal)” (p 635).

Brücker et al (2002) in their analysis of the European situation begin, like Borjas (1999), with a simple theoretical model that shows how less-skilled immigrants are 
more likely to move to countries with generous welfare systems. And again like Borjas, they also point out that immigrant location decisions can also be influenced by factors such as the presence of ethnic networks, whereby the simple predictions of the model can be diluted.

The main aim of their work is to examine differences in the extent of welfare dependency between immigrants and natives across countries (discussed in Section 3 below). However, they also conduct a rudimentary analysis of whether the generosity of welfare systems across countries is correlated with a greater degree of difference between immigrants and natives in their relative receipt of benefits. They define immigrants as being citizens of non-EU countries; citizens of the EU are viewed as "natives" even if they are living in an EU country which is not their country of citizenship. They take their measure of the extent to which immigrants are more intensive users of welfare benefits ${ }^{2}$ and regress it against an OECD summary measure of benefit entitlement. A positive result is found although on the margins of significance.

De Giorgi and Pellizzari (2006) also consider the issue of whether immigrant location decisions are influenced by the generosity of welfare benefits. Like Brücker et al (2002), they use data from the European Community Household Panel and estimate a model of location choice across 14 countries of the pre-enlargement EU. They include measures of wages, unemployment and benefit generosity in their model, along with interaction between these variables and individual characteristics such as age, gender and education levels.

The results suggest that benefits do play a role in determining location choices of immigrants. However, the effect is small, especially when considered relative to the impact of wages; a comparison of coefficient estimates suggests that the wage effect on location choice is ten times that of the benefit impacts. It is also the case that the interactions between benefit levels and individual characteristics are generally insignificant (gender is the one exception, with women being less attracted by highbenefit countries). The simple theoretical models proposed by Borjas (1999) and by

\footnotetext{
${ }^{2}$ We discuss this measure at great length in Section 3 when we return to the Brücker et al (2002) chapter.
} 
Brücker et al (2002) would lead to the expectation that lower-skilled people would be more likely to choose high-benefit locations. The absence of this result in the De Giorgi and Pellizzari analysis would suggest that welfare is not a key factor in determining the nature of the immigrant inflow, in the sense of immigrants who are more likely to be in need of welfare being attracted to high benefit locations.

In spite of the small effect of benefits on location choice uncovered by Giorgi and Pellizzari, they argue that the impact is still sufficient to offset many of the potential benefits of migration in Europe. It is a well-rehearsed argument that inward migration to Europe can help to counteract the adjustment difficulties that arise as a result of its largely immobile native population. But as argued by Giorgi and Pellizzari, if location choices are made partly in response to differences in welfare regimes as opposed to difference in wages and rates of unemployment, this potential benefit of migration is weakened.

As a result of this perceived loss in the benefits of migration, Giorgi and Pellizzari propose the harmonisation of welfare regimes across Europe. At a theoretical level the idea is interesting but the words of George Borjas (quoted above) on the need for care in making policy recommendations based on weak results should possibly be invoked at this point.

Section 3: Do immigrants use welfare more intensively than natives?

The question of whether immigrants use welfare more intensively than natives has generated the most papers in the general area of immigrants and welfare. In this section, we will consider the findings from this research for a number of European countries. Before doing so, we will make a brief reference to the U.S. literature where concerns over welfare use by immigrants led to a curtailment in welfare-related rights of immigrants under the Personal Responsibility and Work Opportunity Act (PRWOA) of 1996. The act imposed a denial for most types of means-tested assistance to non-citizens who arrived after the passage of the legislation and limited the eligibility for many non-citizens who were already in the U.S.. 
Jensen (1988) showed that immigrants in the U.S. were only marginally more likely to be on welfare compared to natives, when unadjusted rates of participation were compared. Once welfare-related characteristics were controlled for, it appeared that immigrant households were less likely to receive benefits. Borjas and Hilton (1996) showed how this small difference between natives and immigrants held when only cash benefits were considered. Once non-cash benefits were included in the analysis, the immigrants were shown to draw more heavily on benefits relative to natives. Borjas and Trejo (1992) showed that more recent immigrants into the U.S. were more likely to be in receipt of welfare relative to earlier arrivals. They also showed that the longer an immigrant household resided in the U.S., the more likely they were to receive benefits. This implied that immigrants assimilated into welfare as opposed to out of it and as such was an important finding.

Borjas (2002) looks at whether the welfare reforms of 1996 led to a greater decline in welfare use among immigrants relative to natives. He concludes that this was not the case in general, apart from the situation in California where immigrant welfare use dropped significantly. Kaestner and Kausal (2005) do find an impact of welfare reform for recently arrived immigrant women. Moreover, they found that the reduction in welfare use by this group was the result of reduced eligibility and not the result of non-take-up of benefits by eligible immigrants (the so-called chilling effect). This was yet another important finding because Borjas (2002) suggests that the fall off in welfare use among immigrants in California that he observed may have been related to such a chilling effect.

We now turn to the European literature in this area. Brücker et al (2002) provide an EU-wide analysis so we will begin with their findings. We will then report on the more detailed analyses within countries and will consider in turn the research for Sweden, Germany, Demark, Norway and Ireland.

Brücker et al (2002) use the European Community Household Panel (1994-1996) to look at the relative rates of welfare receipt for non-EU immigrants in 11 countries of the pre-2004 EU. As with much of the work in this area, their interest is partly in assessing whether differences in receipt rates observed in raw data remains when individual characteristics are controlled for. Put differently, they assess whether there 
is an "immigrant" effect on welfare receipt above and beyond the effects that can arise, for example, if immigrants are less educated on average than the native population.

Their review of the raw data suggests to them that two groups of countries can be defined. In one group of countries, non-EU immigrants have similar rates of welfare use relative to EU citizens and in some cases have even lower rates. The countries in this group are Germany, the UK, Greece, Spain and Portugal. The other group is made up of countries where the rate of welfare receipt among non-EU immigrants is significantly higher than the native population. This group is made up of Denmark, the Netherlands, Belgium, France, Austria and Finland.

As mentioned above, Brücker et al were interested in seeing if these differences disappear once characteristics are controlled for. However, before conducting that analysis they set out a number of reasons why immigrants may rely on welfare to a greater or lesser extent then natives that cannot be explained by their characteristics. It is useful to reproduce these reasons here.

1. Self-selection: Immigrants may have unobserved characteristics that make them more likely to choose to live in a country with more generous welfare benefits.

2. Migration-specific effects: Language problems or psychological trauma could lead immigrants to be more reliant on welfare.

3. Discrimination: Discriminatory practices by employers could see immigrants facing difficulties is securing employment.

4. Network effects: Networks can assist immigrants in obtaining jobs or immigrants may become part of networks that are excluded from mainstream society. Hence, network effects can lead to immigrants being more or less reliant on welfare.

5. Non-portability of entitlements: Immigrants may be excluded from the welfare system in their host countries through legislation.

6. Reduced wages: Any factors which tend to reduce the wages of immigrants, such as exclusion from public sector jobs, will tend to reduce their employment rate and hence will increase their likelihood of being on welfare. 
They consider the question of what they refer to as "residual dependency" on the part of immigrants by estimating probit models of welfare receipt for each country and including a dummy variable indicating non-EU immigrants. A positive and significant coefficient on this variable can be taken as showing an independent impact of immigrant status on welfare receipt. Focusing on their results for unemployment benefits, they find such an immigrant impact in Denmark, the Netherlands, France, Austria, and Finland. No such effect is found for Germany, the UK, Greece and Spain.

We now turn to more detailed country-specific analyses of immigrant-native differences in welfare receipt.

Sweden

Like many of the papers in this area, Hansen and Lofstrom (2003) begin their paper with reference to the increasing use of welfare by immigrants in the country being studied. By way of illustration, they quote the fact that in the mid-1990s expenditure on social assistance for immigrants in Sweden equalled that of natives, even though immigrants made up just 10 percent of the population.

They have two objectives in this paper. They assess whether immigrants in Sweden use welfare more intensively than natives controlling for characteristics that make people more likely to receive welfare. They also assess whether immigrants in Sweden assimilate into or out of welfare. They use longitudinal administrative data (covering the years 1990-1996 and with 300,000 individuals annually), which allow them to address the assimilation issue in a more satisfactory way relative to Borjas and Trejo (1992), who relied on two cross sections as opposed to actual longitudinal data.

Their results reveal the following. The observation of higher welfare receipt among immigrants relative to natives in the unadjusted data remains when observed characteristics are controlled for. This result is in contract to results for Germany (discussed below) where the "raw" differential disappears once relevant 
characteristics are accounted for. They also find that immigrants tend to assimilate out of welfare, in the sense that welfare receipt is shown to fall with length of time in Sweden. This result contrasts with that of Borjas and Trejo (1992) who showed immigrants in the U.S. assimilating into welfare. However, Hansen and Lofstrom (2003) point out that in spite of reductions in welfare use with time spent in Sweden, the rate of convergence is not fast enough to eliminate native-immigrant differences in welfare receipt in the long-run (i.e. 20 years).

Hansen and Lofstrom went on to develop further their understanding of the factor underlying the native-immigrant difference in welfare receipt drawing on the empirical possibilities presented to them from the longitudinal data used in their 2003 paper. In Hansen and Lofstrom (forthcoming), they examine transitions between employment, unemployment and social assistance receipt across natives and immigrants. Of particular interest to them is whether these groups exhibit "structural state dependence" with respect to welfare use. By this they mean the experience of being on welfare in itself increases the probability of remaining on welfare. This is in contrast to a situation in which people are observed to remain on welfare not because of structural state dependence but because they have characteristics which make them more likely to remain on welfare.

They find that refugees do exhibit a greater degree of structural state dependence relative to natives but that for non-refugee immigrants, the degree of state dependence is similar to that of natives. The implication of this is that refugees can become stuck in a welfare trap. For this reason, welfare reform policies aimed at reducing immigrant reliance on welfare have different impacts for refugees and non-refugees, given the different underlying processes that give rise to their presence on welfare.

In Hansen and Lofstrom (2006), they again use administrative, longitudinal data but this time covering a longer time period (1991-2001). The focus of this paper is on transitions in and out of welfare, rather then on transitions across the three states of employment, unemployment and welfare receipt as was the case in Hansen and Lofstrom (forthcoming). They find that differences in the usage of welfare across natives and immigrants are more readily explained by a higher rate of entry into welfare among immigrants as opposed to a lower rate of exit. The results also suggest 
that differences in observable characteristics between natives and immigrants are not the main source of the difference in welfare use between the two groups. Instead, time invariant differences in unobserved characteristics play a larger role. This finding is consistent with the finding in Hansen and Lofstrom (2003).

The findings with respect to the importance of differential entry rates in explaining the native-immigrant gap in welfare use suggest that policy should aim to reduce entry as opposed to focusing on exits. However, implementing such a policy stance is difficult as it may not be clear as to precisely which individual immigrants are more likely to enter welfare. The practice of profiling may be considered but this remains a largely untested approach to policy implementation.

The Swedish case has also been considered by Andrén (2007). In a development of the work of Hansen and Lofstrom, he also looks at the issue of welfare receipt in a dynamic framework and focuses his attention on the question of structural state dependence. He estimates a dynamic discrete choice model and finds that while state dependence is observed for both native Swedes and immigrants, the effect is estimated to be three times larger for immigrants. This again leads to the policy conclusion that efforts should be made to prevent immigrants from entering welfare but the point made above on the feasibility of such policies is relevant again.

\section{Germany}

As with the U.S. and the Swedish, Castronova et al (2001) motivate their analysis of the take-up of welfare payments by immigrants in Germany with reference to the higher rate of take-up among this group relative to natives. They quote earlier research as showing that immigrants in Germany were 3.7 times more likely to be in receipt of benefits relative to natives (Frick et al, 1999). In an effort to explain this immigrant-native difference, they pose the following question. Are immigrants more likely to receive benefits because they have higher rates of eligibility or because they have higher rates of take-up, conditional on eligibility? Castronova et al see this as being an important distinction for political reasons. As they put it "a group with high eligibility rates, all else equal, may be considered economically unfortunate or even 
victimised” (p 728). In contrast, “a group with high take-up rates is less likely to be granted such sympathies” (p728).

Unlike other studies in this area, they attempt to estimate eligibility for welfare benefits for each household in their sample based on household income and composition. They maintain that this is more easily done in the case of Germany relative to, for example, the U.S. where the complexities of the welfare system make such estimation more difficult. Once they have their eligibility estimates, they can go on to assess whether the immigrant-native difference is due to eligibility or take-up (or both).

Their results show that immigrants in Germany are no more likely to take-up welfare benefits relative to natives, given their eligibility. However, they are more likely to be eligible as a result of their incomes and household structures. Although the result is reported in these terms by Castronova et al, the results can also be thought of in terms of the observable characteristics of the immigrants "explaining” their higher reliance on welfare as opposed to their immigrant status per se.

Riphahn (2004) also examines the German case but poses the research question along the more typical lines of whether the observed differences in take-up of welfare between natives and immigrants can be explained by characteristics. She also looks at whether immigrants assimilate out of or into welfare and whether the determinants of welfare receipt differ in their impacts across the two groups.

As with the Castronova et al (2001) study, Riphahn (2004) finds that the characteristics of immigrants explain their relatively intensive use of welfare and there is no "immigrant effect". She fails to find assimilation effects, in the sense of immigrants being more likely to receive benefits as they spend longer in Germany. She does find that the impact of dropping out of the labour force is a much stronger predictor of welfare receipt among immigrants relative to natives.

Given her finding that it is immigrants' characteristics, and not their behaviour, which gives rise to higher welfare use, Riphahn (2004) draws the policy conclusion that the issue should be tackled through immigration policy and not through changing 
eligibility rules. Her argument is based on the notion that states can best achieve immigrant-related outcomes by influencing the selection of immigrants at the point of entry as opposed to altering outcomes post arrival. In this way, the argument is equivalent to that made by the proponents of skill-based admission criteria in the context of desired labour market outcomes.

\section{Denmark}

Nannestad (2004) approaches the issue of immigrants and welfare in Denmark from the broader perspective of the long-run sustainability of the welfare state in the context of population ageing. His overall conclusions are negative with respect to the impact of immigration (at least from non-Western countries) on Denmark. He motivates his discussion of the topic by presenting the familiar argument that immigration can potentially act to offset the fiscal pressures associated with population ageing. However, he then goes on to demonstrate that immigrants in Denmark from non-Western countries have tended to be net beneficiaries of the welfare state (drawing on Wadensjö and Orrje, 2002) and that they remain netbeneficiaries even after ten years of residence in Denmark.

He discusses how this situation arises because of poor labour market outcomes for non-Western immigrants and also discusses how these poor outcomes are also present among the second generation. And while he does not attempt to show empirically that the generous welfare provisions in Denmark give rise to an inflow of low-skilled immigrants, he suggests that such a mechanism is in operation. As he puts it, "while immigrants as a whole are probably favourably self-selected (Chiswick, 2000), the Danish welfare state may be most attractive to immigrants with a relatively low market value»33 (p 760).

For Blume and Verner (2007), the core question is whether the relatively high usage of welfare services by immigrants in Denmark declines with time spent there. Hence, they are building on the welfare-assimilation studies of Borjas and Trejo (1992), Hansen and Lofstrom (2003) and Riphahn (2004). They find that for male immigrants

\footnotetext{
${ }^{3}$ He quotes Borjas (1999) as providing support for this view.
} 
from developed countries, rates of welfare receipt do converge on those of native men. For men from less developed countries, assimilation out of welfare occurs to a degree but rates of receipt remain well above those for native men. For female immigrants, some degree of assimilation out of welfare also occurs but it is weaker than that for men. This finding on assimilation out of welfare leads Blume and Verner to suggest that only immigrants who arrive at a very young age are likely to be “profitable” for Denmark, at least when viewed from the fiscal perspective.

\section{Norway}

The focus of the paper by Bratsberg et al (2007) is on the long-run labour market outcomes for immigrants in Norway but they steer into the area of welfare when trying to explain the labour market patterns that they observe. Using administrative data, they follow a group of "regular" male labour market immigrants (i.e. not refugees and family reunification immigrants) who arrived in Norway between 1971 and 1975 from Pakistan, India, Turkey and Morocco up to 2000. As they themselves conclude, the findings with regard to labour market outcomes are “dismaying” (p 3).

At the outset of the period under review, the immigrant group had an employment rate of 96 percent, above that of the native comparison group. By 2000, the employment rate of the immigrants had fallen to 50 percent, substantially below the native comparison employment rate of 87 percent. They offer a number of explanations, including the impact of the welfare system. According to Bratsberg et al, some aspects of the welfare system combined to provide a high proportion of the immigrant group with high replacement ratios. For example, as the immigrants typically had higher numbers of children, their payments were inflated accordingly.

Ireland

The comparisons between immigrants and natives in terms of receipt of welfare is noteworthy in Ireland because, unlike all the examples looked at so far, immigrants in Ireland are reported by Barrett and McCarthy (2007) as being less intensive users of welfare. The unadjusted figures suggest that immigrants are only half as likely to be in receipt of welfare payments. As immigrants in Ireland are also unusual in having 
levels of educational attainment that are higher than the native population, Barrett and McCarthy go on to consider the issue of differential rates of welfare receipt controlling for standard socio-economic factors.

They find that the lower rate of welfare receipt among immigrants remains even when controlling for relevant characteristics. They also show that unemployed immigrants are substantially less likely to be on welfare relative to unemployed natives. While this could be because of lower eligibility rates or lower take-up rates, one element of Ireland's welfare code points to the potential importance of eligibility. Immigrants must have been resident for at least two years in Ireland before they become eligible for welfare payment. As the data that Barrett and McCarthy used relates to 2004 and many of Ireland's immigrants are recent arrivals, the observed pattern could well be the result of this exclusion clause in the welfare code.

Section 4: Do contextual factors increase the likelihood of immigrants receiving benefits?

The papers discussed in Section 3 focused on immigrant-native differences in welfare receipt. In this section, we look at a somewhat different strand of research in which the impact of immigrant networks on immigrant welfare receipt is discussed. The literature on immigration contains many references to the importance of networks in facilitating migration and in influencing location decisions. Networks are believed to reduce the costs of migration and to facilitate the process by initially providing accommodation and then by providing information on employment opportunities or direct contact with prospective employers. In the context of welfare use, the question that arises is whether the existence of co-ethnic networks leads to a reduced need for welfare or to an increased usage, as a result of information provision or the creation of a social acceptability around welfare receipt.

Borjas and Hilton (1996) touch on this issue in their broader analysis of differences in the use of welfare between immigrants and natives (discussed above). They observe that the types of benefits received by earlier immigrant inflows are correlated with the type of benefit received by later inflows. This raises the possible existence of network effects whereby information is passed onto new arrivals within immigrant groups. 
Hao and Kawano (2001) look again at this network question for the U.S. but they do so in a more direct way than Borjas and Hilton (1996). As they put it, most of the earlier work looking at welfare receipt of immigrants has focused on the impact of human capital so they attempt to add a "social capital" dimension to the analysis. They do so in two ways. Firstly, they add a measure of contact with co-ethnics to the standard models of welfare receipt. This is intended to capture the possible flow of information. Second, the also add a variable measuring the degree of economic inactivity among co-ethnics in the vicinity of each immigrant. This is meant to capture a possible lack of information on employment opportunities.

They analyse two specific cases of welfare receipt: payment to single mothers and to the elderly. In the case of single mothers, the measure of contact with co-ethnics is not significant but the measure of economic inactivity among co-ethnics is. This leads Hao and Kawano to conclude that information provided to single mothers on employment is more important than information on welfare. For the elderly, both coethnic contact and economic activity among co-ethnics emerge as significant. The interpretation put on this by the authors is that "co-ethnic networks support (elderly immigrants') use of SSI through normative justification, reduction of welfare stigma and the elderly support strategy of relying on the government rather than on the family"(p388).

Äslund and Fedriksson (2005) look at the same issue but this time for Sweden. The approach they take is quasi-experimental in nature and allows them to overcome the problem that arises when trying to draw conclusions about neighbourhood affects on individuals when individuals chose the neighbourhoods in which they live. They draw on a government programme in Sweden in the late 1980s whereby refugees were assigned to live in a municipality chosen for them. They go on to assess how the numbers of co-ethnics living close by and the extent to which these co-ethnics use welfare, affected immigrants' propensity to use welfare. They refer to the number of co-ethnics as a "quantity" dimension of the analysis and the rate of welfare usage among co-ethnics as the "quality” dimension. 
The results suggest that it is the quality dimension that matters and not the quantity dimension. The rate of welfare usage by individuals increases by almost 7 percent when the fraction of welfare dependents in the ethnic group increases by 10 percent. This result on the importance of quality as opposed to quantity remains when the analysis is broken down by different groups.

\section{Section 5: Two empirical illustrations}

By way of illustrating further some of the issues raised above, we undertook analyses of the rates of welfare receipt for immigrants and natives in Ireland and the UK. The approach is along the lines of Brücker et al (2002) in that we estimate probit models of welfare receipt, including dummy variables indicating individuals who are immigrants, along with other controls. Significant coefficients on the immigrant dummy variables can then be taken as evidence of an immigrant effect on welfare receipt, either positive or negative.

Beginning with the Irish case, the data on which the analysis below is based come from the Irish element of the EU Survey on Income and Living Conditions (EUSILC) for $2005^{4}$. A full description of the sampling methodology can be found in Central Statistics Office (2006) but here we will set out the broad features of the survey. The EU-SILC is a voluntary survey of private households and is carried out under EU legislation. To date, it has been used mainly to provide information on the rates of poverty and deprivation in Ireland (CSO, 2006). The survey seeks to provide a nationally representative sample of households.

For each individual, the survey contains information on variables such as age, education, labour force status and earnings. It also contains information on whether or not each individual is in receipt of a wide range of social welfare payments. Crucially for our purposes, the place of birth and citizenship of each respondent is provided and we use these to identify the immigrants in the sample. If an individual reports themselves as having been born in Ireland and as being an Irish citizen, we code them as being a native. If an individual reports that they were born outside of Ireland and

\footnotetext{
${ }^{4}$ In essence, this analysis updates Barrett and McCarthy (2007) which was based on the 2004 wave of the EU-SILC.
} 
that they are not Irish citizens, we code them as being immigrants. In addition, we take their reported citizenship to describe where they are from.

We base our analysis on a sample of 7,341 individuals. Of these almost 7,000 are natives and just over 300 are immigrants. Of the immigrants, about 150 are from the English-speaking countries of the UK, the US, Canada, Australia, New Zealand and South Africa. The remainder (again about 150) are from elsewhere which we take to be non-English-speaking countries, although this may be an oversimplification. We focus on adults aged less than 65 and as such we are not including old-age pension payments in the analysis. Instead, we limit attention to four types of payment unemployment benefits and insurance and disability benefits and insurance.

The raw data show that 18 percent of the natives in the sample received a welfare payment in the previous twelve months, compared to 10.7 percent of the immigrants. However, the raw data also show that the immigrants are more highly educated than the native population. For example, while 15.7 percent of the natives in the sample report themselves as having a third level degree, the corresponding figure for immigrants is 39.3 percent. These figures mirror those from other work on Ireland's immigrants.

In order to see if the lower rate of welfare receipt among Irelands immigrants is solely related to their high level of education, we estimate multivariate probit models of welfare receipt. Our first probit model is shown in Table 1. Looking firstly at the coefficients other than the immigrant dummies, we see that higher levels of education are associated with lower rates of welfare receipt. We also see both married men and married women are less likely to receive welfare payments relative to single people. The likely explanation for this is that being married may reduce the likelihood of receiving means-tested assistance as a husband's or wife's income is taken into account when assessing eligibility.

Turning to the immigrant dummy variable, Model 1 shows that immigrants in total are 4 percent less likely to be in receipt of welfare payments. However, if we look at Model 2, we see that this aggregate figure hides differences between immigrants from English-speaking countries and from non-English speaking countries. There is no 
difference between the English-speaking group and the natives. But for immigrants from non-English-speaking countries, the gap is welfare receipt relative to natives rises to 8 percent.

When reviewing the Barrett and McCarthy (2007) analysis above (based on Irish data from a year earlier), the point was made that a two-year residency requirement for welfare receipt was likely to lie behind this result of lower immigrant welfare receipt. The different pattern by national groups is also consistent with this explanation because most of the more recent arrivals were from the EU New Member States and so were in the non-English speaking group.

As a further line of analysis we looked at natives and immigrants who described themselves as being unemployed to see if the pattern from Table 1 remains for this restricted group. If immigrants were substantially less likely to be unemployed, this could partly explain the results in Table 1 . As can be seen from Table 2, the lower usage of welfare services is much stronger for immigrants in the restricted subsample. However, the pattern across the national groups remains with all of the difference between natives and immigrants being related to immigrants from nonEnglish-speaking countries.

In the final element of the analysis of the Irish data, we used the information included in the data on the amount of benefits received to see if there were differences between immigrants and natives. We ran tobit models across the full sample and found that immigrants from non-English-speaking countries received over $€ 3,000$ less in payments in the previous year relative to natives. There was no significant difference in the amounts received by immigrants from English-speaking countries and natives. We need to be careful in interpreting this result as it might relate in part to immigrants arriving into the welfare system during the course of the year and so their reported payments relating only to a part of that year. But whatever the reason, the results do not point to immigrants placing a burden on the Irish welfare state.

Turning to the rate of welfare receipt for immigrants and natives in the UK, the data on which this section of the analysis are based are from the British Household Panel Survey (BHPS). Full details of this survey are available from Taylor et al (2007), but 
here we provide a brief summary. The BHPS is a nationally representative random sample that was designed as an annual survey of each adult member of more than 5,000 households, making a total of approximately 10,000 interviews in the original sample in 1991. The same individuals are re-interviewed each year and if they move to a new household, then all adult members of the new household are interviewed also. Children are also interviewed once they reach 16 years of age. The most recent wave of the BHPS (Wave 15) pertains to the year 2005, and is employed in this analysis.

The BHPS contains a wide array of information, including data on household structure, the labour market, income and wealth, social welfare receipt, health and social economic variables. Individuals are also asked about their citizenship status and we use this to identify immigrants in our sample. More specifically, immigrants in the UK are defined as those individuals who report their citizenship as non-British, while natives in Britain are defined as those individuals who report their citizenship as British and who do not possess a dual citizenship with any other country. This leaves us with a sample of 11,323 individuals, 10,852 of which are defined as British natives and 471 as immigrants. As in the case of Ireland, we restrict our study to individuals aged less than 65 years, and focus only on disability and unemployment benefits when analysing welfare receipt.

The raw data show that 19 percent of immigrants and 12 percent of natives received welfare payments in the period in question. Hence, unlike Ireland, the situation in the U.K. is like that in most of the countries reviewed, with immigrants being more likely to receive welfare payments. We now want to assess if a difference remains once characteristics of controlled for.

Table 3 below presents the result of our first probit in which the dependent variable is equal to one if the individual received a social welfare payment at any point in the last year. In Model 1, we look at the entire immigrant group. The independent variables show that individuals who report themselves as single are more likely to draw on social welfare than married persons (similar to the Irish case), while married females are more likely than married males to be in receipt of social welfare. Similarly more highly educated individuals are less likely to use social welfare while older 
individuals are more likely. The variable 'Child under 12' is equal to 1 if the individual reported themselves as being responsible for a child under 12 years of age. The results show that individuals with dependent children under 12 years are less likely to use social welfare. Finally, turning to our immigrant variable, the results show that immigrants in our sample are 4 percent more likely to use social welfare than natives, controlling for the above-mentioned factors. ${ }^{5}$

In Model 2 of Table 3 we split our immigrants into an English speaking group ${ }^{6}$ and a non-English speaking group and re-run our probit. We have 369 English-speaking immigrants in our sample and 102 non-English speaking immigrants. The results suggest that immigrants from English-speaking countries are 7 percent more likely to use social welfare than natives while non-English speaking immigrants are about 5 percent less likely. The results are significant. The contrast between these results suggests that knowledge of the welfare system may be important in determining receipt.

We went on to examine whether this higher propensity among immigrants remained when we looked within categories defined by educational attainment or employment status. Immigrants in the sample tend to be less highly educated than natives. For example, while 46 percent of natives have a high level of education (third level degree or above) the figure for immigrants is 39 percent. In order to see if the immigrantnative differential held for less educated people, we re-ran our original probit, this time including only the group with a low level of educational attainment. As shown in Model 1 of Table 4, the immigrants were still more likely to be in receipt of social welfare within this lower educated group.

We also re-ran the probit looking at the unemployed group only. At this stage, our sample size is quite small and we are left with only 410 natives and 22 immigrants. The results are shown in Model 2 of Table 4. The results show that immigrants are 4 per cent more likely to be in receipt of social welfare than natives. However, the

\footnotetext{
${ }^{5}$ This result is somewhat similar to that of Brücker et al (2002) who find that immigrants in the UK were 8 percent more likely to use unemployment benefits relative to natives, controlling for observable characteristics.

${ }^{6}$ English speaking immigrants are defined as those coming from countries where English is the main language. We include Ireland, North America, Australia, New Zealand, South Africa and Malta under this heading.
} 
coefficient on our immigrant dummy is not significant at the 5 percent level, so we cannot be definitive on this point.

These results appear to show that immigrants in the U.K. share the characteristic of those in Sweden of being more intensive users of welfare even when characteristics are controlled for. As the U.K., like Ireland, imposed restriction on welfare use among newly arrived immigrants in the context of EU accession in 2004, we tried to see if the higher rate of welfare receipt was reversed among immigrants from the EU's New Member States. Unfortunately, there were only ten such immigrants in the sample and so the analysis was not possible.

\section{Section 6: Conclusions}

Having reviewed the economics literature on immigrants and welfare, and also having provided a modest addition, the question that we now want to address is whether there are clear policy lessons to be drawn. In order to do that, we need to a have a view on what we want immigration to achieve. This is a controversial topic in itself so here we will simply take the following guideline provided by Borjas (1995): “if we are willing to maintain the hypothesis that immigration policy should increase the national income of natives, the government's objective function when setting immigration policy is well defined: maximise the immigration surplus ${ }^{7}$ net of the fiscal burden imposed by immigrants on native taxpayers” (p 18). Thinking in these terms, we can ask if there is evidence to suggest that the welfare dimension of the immigration phenomenon works against the attainment of this objective.

Regarding the question of whether generosity in the welfare system leads to an inflow of likely welfare recipients, the evidence is both thin (in the sense of a very limited number of studies) and weak (in the sense of results being either on the margins of significance or quantitatively minor). It could well be the case that other factors, such as the prior existence of networks or favourable labour market conditions, have much stronger influences on location decisions.

\footnotetext{
${ }^{7}$ In essence, the immigration surplus can be thought of as the extra output that is produced as a result of immigration that is not appropriated by the immigrants themselves.
} 
As to the relative usage of welfare by immigrants and natives, the general picture to emerge is one of higher immigrant use. The studies for Germany showed that this higher usage can be explained by characteristics and the studies for Sweden showed some evidence of assimilation out of welfare. However, it remains the case that most of the studies showed a higher rate of receipt among immigrants and this contributes to increasing the fiscal burden. It also appears to be the case that immigrant receipt of welfare can generate additional receipt through both structural state dependence and through network effects.

If we accept that immigrants are generally drawing more heavily on the welfare state (for whatever reason) the next question to arise is how this can be contained. The Irish case illustrates the two possible directions. First, as with labour market dimensions of immigration policy, a more favourable selection of immigrants at the point of entry will lead to better outcomes. However, as a result of asylum conventions and family reunification provisions in immigration law, such selection is not always possible. Second, by simply denying welfare to immigrants even for a period of time, the apparent tendency of immigrants to use welfare more intensively can be reduced. But again, this is not always a simple route for policy. It may not be possible (legally) to deny benefits to certain groups and, as Borjas (2002) shows, the reactions of immigrants to welfare changes can offset the intended effects of those changes. In the case he considers, the denial of welfare benefits to non-citizens in the U.S. in 1996 led to an increase in the number of immigrants applying for citizenship.

While there may remain scope for policy to influence immigrant welfare usage through entry selection processes and through limiting eligibility, it may also be the case that the existence of welfare codes in the context of immigration will almost inevitably lead to greater degrees of immigrant welfare receipt. This can arise in part from low degrees of transferability of human capital and hence an element of labour market disadvantage. It can also arise from lower levels of educational attainment in sending countries. If this is the case, then polices aimed at welfare recipients generally may be the most appropriate route for tackling immigrant welfare receipt. 
Tables

Table 1: Probit Results of Welfare Participation in Ireland (Dependent Variable: Social Welfare Recipient)

\begin{tabular}{|c|c|c|c|c|}
\hline & \multicolumn{2}{|c|}{ Model 1} & \multicolumn{2}{|c|}{ Model 2} \\
\hline & \multicolumn{4}{|c|}{ Marginal Std. Error Marginal Std. Error } \\
\hline & \multicolumn{2}{|l|}{ Impact } & \multicolumn{2}{|l|}{ Impact } \\
\hline Immigrant & -0.04 & 0.02 & & \\
\hline Immigrant:English Speaking Country & & & 0.00 & 0.03 \\
\hline Immigrant: Non-English Speaking Country & & & -0.08 & 0.02 \\
\hline Single Female* & -0.01 & 0.01 & -0.01 & 0.01 \\
\hline Married Male* & -0.09 & 0.01 & -0.09 & 0.01 \\
\hline Married Female* & -0.10 & 0.01 & -0.10 & 0.01 \\
\hline Years Worked & 0.00 & 0.00 & 0.00 & 0.00 \\
\hline$(\text { Years Worked) })^{2}$ & 0.00 & 0.00 & 0.00 & 0.00 \\
\hline Second Level** & -0.11 & 0.01 & -0.11 & 0.01 \\
\hline Third Level** & -0.14 & 0.01 & -0.14 & 0.01 \\
\hline $\mathrm{N}$ & \multicolumn{2}{|c|}{7,341} & \multicolumn{2}{|c|}{7,341} \\
\hline LRchi $^{2}$ & \multicolumn{2}{|c|}{372.27} & \multicolumn{2}{|c|}{376.61} \\
\hline Prob $>$ chi $^{2}$ & \multicolumn{2}{|c|}{0.0000} & \multicolumn{2}{|c|}{0.0000} \\
\hline Psuedo $\mathrm{R}^{2}$ & \multicolumn{2}{|c|}{0.0544} & \multicolumn{2}{|c|}{0.0551} \\
\hline
\end{tabular}

Note:* Omitted category is Single Male

**Omitted category is Primary Education or Less than Second Level 
Table 2: Probit Results of Welfare Participation in Ireland for Unemployed Group only (Dependent Variable: Social Welfare Recipient)

\begin{tabular}{|c|c|c|c|c|}
\hline & \multicolumn{2}{|c|}{ Model 1} & \multicolumn{2}{|c|}{ Model 2} \\
\hline & \multicolumn{4}{|c|}{ Marginal Std. Error Marginal Std. Error } \\
\hline & Impact & & Impact & \\
\hline Immigrant & -0.36 & 0.14 & & \\
\hline Immigrant:English Speaking Country & & & 0.07 & 0.19 \\
\hline Immigrant: Non-English Speaking Country & & & -0.62 & 0.12 \\
\hline Single Female & -0.04 & 0.09 & -0.04 & 0.09 \\
\hline Married Male & -0.28 & 0.10 & -0.27 & 0.10 \\
\hline Married Female & -0.36 & 0.13 & -0.33 & 0.14 \\
\hline Years Worked & 0.01 & 0.01 & 0.01 & 0.01 \\
\hline$(\text { Years Worked })^{2}$ & 0.00 & 0.00 & 0.00 & 0.00 \\
\hline Second Level* & -0.13 & 0.07 & -0.12 & 0.07 \\
\hline Third Level** & 0.02 & 0.12 & 0.04 & 0.12 \\
\hline $\mathrm{N}$ & \multicolumn{2}{|c|}{237} & \multicolumn{2}{|c|}{237} \\
\hline LRchi $^{2}$ & \multicolumn{2}{|c|}{30.26} & \multicolumn{2}{|c|}{37.04} \\
\hline Prob $>$ chi $^{2}$ & \multicolumn{2}{|c|}{0.0002} & \multicolumn{2}{|c|}{0.0000} \\
\hline Psuedo $\mathrm{R}^{2}$ & \multicolumn{2}{|c|}{0.1052} & \multicolumn{2}{|c|}{0.1288} \\
\hline
\end{tabular}

Note: * Omitted category is Single Male

**Omitted category is Primary Education or Less than Second Level 
Table 3: Probit Regression Results of Welfare Participation in the UK (Dependent Variable: Social Welfare Receipt)

\begin{tabular}{|c|c|c|c|c|}
\hline & \multicolumn{2}{|c|}{ Model 1 } & \multicolumn{2}{|c|}{ Model 2} \\
\hline & $\begin{array}{c}\text { Marginal } \\
\text { Impact }\end{array}$ & Std. Error & $\begin{array}{l}\text { Marginal } \\
\text { Impact }\end{array}$ & Std. Error \\
\hline Immigrant & 0.04 & 0.01 & & \\
\hline Immigrant: English Speaking Country & & & 0.07 & 0.02 \\
\hline Immigrant: Non-English Speaking Country & & & -0.05 & 0.01 \\
\hline Single Male* & 0.06 & 0.01 & 0.06 & 0.01 \\
\hline Single Female* & 0.08 & 0.01 & 0.08 & 0.01 \\
\hline Married Female* & 0.03 & 0.01 & 0.03 & 0.01 \\
\hline Age & 0.01 & 0.00 & 0.01 & 0.00 \\
\hline$(\text { Age })^{2}$ & 0.00 & 0.00 & 0.00 & 0.00 \\
\hline Medium Education** & -0.04 & 0.01 & -0.04 & 0.01 \\
\hline Higher Education** & -0.09 & 0.01 & -0.09 & 0.01 \\
\hline Child Under 12 & -0.05 & 0.01 & -0.05 & 0.01 \\
\hline $\mathrm{N}$ & \multicolumn{2}{|c|}{11,323} & \multicolumn{2}{|c|}{11,323} \\
\hline LRchi2 & \multicolumn{2}{|c|}{908.80} & \multicolumn{2}{|c|}{922.54} \\
\hline Prob $>$ chi2 & \multicolumn{2}{|c|}{0.0000} & \multicolumn{2}{|c|}{0.0000} \\
\hline Psuedo R2 & \multicolumn{2}{|c|}{0.1270} & \multicolumn{2}{|c|}{0.1289} \\
\hline
\end{tabular}

* Omitted category is Married Male

** Omitted category is Lower Education 
Table 4: Probit Regression Results of Welfare Participation in the UK (Dependent Variable: Social Welfare Receipt)

Model 1

Model 2

Lower Educated Group Unemployed Group

Marginal Std. Error Marginal Std. Error

Immigrant Impact

Impact

Single Male*

0.09

0.03

Single Female*

0.08

0.02

0.04

0.08

Married Female*

0.12

0.02

$-0.03$

0.04

0.04

0.02

0.03

0.05

Age

0.03

0.00

$-0.09$

0.03

(Age) ${ }^{2}$

0.00

0.00

0.01

0.01

Medium Education**

0.00

0.00

Higher Education**

$-0.05$

0.03

Child Under 12

$-0.12$

$\mathrm{N}$

LRchi2

Prob > chi2

Psuedo R2

$-0.10$

0.03

$-0.12$

4,459

401.31

432

0.0000

32.57

0.1014

0.0001

0.0977

* Omitted category is Married Male

** Omitted category is Lower Education 


\section{References}

Ardrén, Thomas (2007), “The Persistence of Welfare Participation”, IZA Discussion Paper No. 3100

Äslund, Olof and Peter Fedriksson (2005), “Ethnic Enclaves and Welfare Cultures: Quasi-Experimental Evidence”, IZA Discussion Paper No. 1536

Barrett, Alan and Yvonne McCarthy (2007), "Immigrants in a Booming Economy: Analysing their Earnings and Welfare Dependence”, Labour Vol. 21 No. 4-5 pp. 789808

Blume, Kræn and Mette Verner (2007), "Welfare Dependency among Danish Immigrants”, European Journal of Political Economy Vol. 23 No. 2 pp. 453-471

Bratsberg, Bernt, Oddbjørn Raaum and Knut Røed (2007), "When Minority Labor Migrants Meet the Welfare State”, IZA Discussion Paper No. 2872

Borjas, George J. (2002), "Welfare Reform and Immigrant Participation in Welfare Programs”, International Migration Review Vol. 36 No. 4 pp. 1093-1123

Borjas, George J. (1999), “Immigration and Welfare Magnets”, Journal of Labour Economics Vol. 17 No. 4 Part 1 pp. 607-637

Borjas, George J. (1995), “The Economic Benefits of Immigration”, Journal of Economic Perspectives Vol. 9 No. 2 pp. 3-22

Borjas, George J. and Lynette Hilton (1996), "Immigration and the Welfare State: Immigrant Participation in Means-tested Entitlement Programs”, Quarterly Journal of Economics Vol. 111 No. 2 pp 575-604

Borjas, George J. and Stephen J. Trejo (1991), "Immigrant Participation in the Welfare System”, Industrial and Labor Relations Review Vol. 44 No. 2 pp. 195-211

Brücker, Herbert, Gil S. Epstein, Barry McCormick, Gilles Saint-Paul, Alessandra Venturini and Klaus Zimmermann (2002), "Welfare State Provision”, chapter 5 in Boeri, Tito, Gordon Hanson and Barry McCormick eds. Immigration Policy and the Welfare State, Oxford: Oxford University Press

Castronova, Edward J., Hilke Kayser, Joachim R. Frick and Gert G. Wagner (2001), "Immigrants, Natives and Social Assistance: Comparable Take-up under Comparable Circumstances”, International Migration Review Vol. 35 No. 3 pp 726-748

Central Statistics Office (2006), EU Survey on Income and Living Conditions, Dublin: CSO

Chiswick, Barry (2000), “Are Immigrants Favorably Self-selected?”, IZA Discussion Paper No. 131

De Giorgi, Giacomo and Michele Pellizari (2006), "Welfare Migration in Europe and the Cost of a Harmonised Social Assistance”, IZA Discussion Paper No. 2094 
Frick, J.R., T.M. Smeeding and G.G. Wagner (1999), "Immigrants in Two Modern Nations: Characteristics of the Foreign and Native Born Populations in Germany and the United States”, Vierteljahrshefte zur Wirtschaftsforchung Vol. 68 No. 2 pp 297307

Hansen, Jörgen and Magnus Lofstrom (forthcoming), “The Dynamics of Immigrant Welfare and Labor Market Behaviour”, Journal of Population Economics

Hansen, Jörgen and Magnus Lofstrom (2006), "Immigrant-Native Differences in Welfare Participation: The Role of Entry and Exit Rates", IZA Discussion Paper No. 2261

Hansen, Jörgen and Magnus Lofstrom (2003), “Immigrant Assimilation and Welfare Participation: Do Immigrants Assimilate into or out of Welfare?”, Journal of Human Resources Vol. 38 No. 1 pp. 74-98

Hao, Lingxin and Yukio Kawano (2001), "Immigrants Welfare Use and Opportunity for Contact with Co-Ethnics”, Demography Vol. 38 No. 3 pp. 375-389

Jensen, Leif (1988), "Patterns of Immigration and Public Assistance Utilization”, International Migration Review Vol. 22 No. 1 pp. 51-83

Kaester, Robert and Neeraj Kaushal (2005), “Immigrant and Native Responses to Welfare Reform”, Journal of Population Economics Vol. 18 pp. 69-92

Nannestad, Peter (2004), “Immigration as a Challenge to the Danish Welfare State?”, European Journal of Political Economy Vol. 20 No. 3 pp. 755-767

Riphahn, Regina T. (2004), "Immigration Participation in Social Assistance Programs”, Applied Economics Quarterly Vol. 50 No. 4

Taylor, Marcia Freed (ed). with John Brice, Nick Buck and Elaine Prentice-Lane (2007), British Household Panel Survey User Manual Volume A: Introduction, Technical Report and Appendices, Colchester: University of Essex.

Wadensjö, E. and H. Orrje (2002), Immigration and the Public Sector in Denmark, Aarhus, Aarhus University Press 